\title{
Increased papillae growth and enhanced short-chain fatty acid absorption in the rumen of goats are associated with transient increases in cyclin D1 expression after ruminal butyrate infusion
}

\author{
Moolchand Malhi, ${ }^{*}$ Hongbing Gui,, ${ }^{*}$ ei Yao, ${ }^{*}$ Jörg R. Aschenbach, † Gotthold Gäbel,§ and Zanming Shen*1 \\ *Laboratory of Animal Physiology and Biochemistry, Nanjing Agriculture University, 210095 Nanjing, China \\ †Institute of Veterinary Physiology, Free University of Berlin, 14163 Berlin, Germany \\ §Institute of Veterinary Physiology, Faculty of Veterinary Medicine, University Leipzig, 04103 Leipzig, Germany
}

\begin{abstract}
We tested the hypothesis that the proliferative effects of intraruminal butyrate infusions on the ruminal epithelium are linked to upregulation in cyclin D1 (CCND1), the cyclin-dependent kinase 4 (CDK4), and their possible association with enhanced absorption of short-chain fatty acids (SCFA). Goats $(\mathrm{n}=23)$ in 2 experiments (Exp.) were fed $200 \mathrm{~g} / \mathrm{d}$ concentrate and hay ad libitum. In Exp. 1, goats received an intraruminal infusion of sodium butyrate at 0.3 (group $\mathrm{B}, \mathrm{n}=8$ ) or 0 (group $\mathrm{C}, \mathrm{n}=7$ ) $\mathrm{g} / \mathrm{kg}$ of body weight $(\mathrm{BW}$ ) per day before morning feeding for $28 \mathrm{~d}$ and were slaughtered 8 $\mathrm{h}$ after the butyrate infusion. In Exp. 2, goats $(\mathrm{n}=8)$ received butyrate infusion and feeding as in Exp. 1. On d 28, epithelial samples were biopsied from the antrium ruminis at 0,3 , and $7 \mathrm{~h}$ after the last butyrate infusion. In Exp. 1, the ruminal molar proportional concentration of butyrate increased in group B by about $110 \%$ after butyrate infusion and remained elevated for 1.5 $\mathrm{h}$; thereafter, it gradually returned to the baseline (preinfusion) level. In group C, the molar proportional concentration of butyrate was unchanged over the time points. The length and width of papillae increased in $\mathrm{B}$ compared with $\mathrm{C}$; this was associated with increased numbers of cells and cell layers in the epithelial strata and an increase in the surface area of $82 \%$. The mRNA expression of CCND1 increased transiently at $3 \mathrm{~h}$ but returned to the preinfusion level at $7 \mathrm{~h}$ following butyrate infusion in Exp. 2. However, it did not differ between $\mathrm{B}$ and $\mathrm{C}$ in Exp. 1, in which the ruminal epithelium was sampled at $8 \mathrm{~h}$ after butyrate infusion. The mRNA expression of the monocarboxylate transporter $M C T 4$, but not $M C T 1$, was stably upregulated in B compared with $\mathrm{C}$. The estimated absorption rate of total SCFA $(\% / \mathrm{h})$ increased in B compared with C. We conclude that transient increases in cyclin D1
\end{abstract}

Received February 15, 2013.

Accepted August 22, 2013.

${ }^{1}$ Corresponding author: zmshen@njau.edu.cn transcription contribute to butyrate-induced papillae growth and subsequently to the increased absorption of SCFA in the ruminal epithelium of goats.

Key words: butyrate, rumen papillae growth and short-chain fatty acid absorption, cyclin D1 and monocarboxylate transporters, goat

\section{INTRODUCTION}

Large quantities of short-chain fatty acids (SCFA) are produced and absorbed in the rumen, which supplies 70 to $80 \%$ of energy in ruminants (Bergman, 1990). Absorption of SCFA takes place in both the protonated SCFA form via simple diffusion and the anionic SCFA form via carrier-mediated transport (Koho et al., 2005; Aschenbach et al., 2009, 2011). In addition to effects of epithelial blood flow (Dobson, 1984; Storm et al., 2011, 2012) and rumen motility (Stern et al., 1970; Kendall and McLeay 1996), the absorption rates of SCFA are primarily influenced by the papillae surface area (Dirksen et al., 1984; Gäbel et al., 1991a,b) and the availability of transport proteins. Generally, the larger the surface area, the greater the absorption rate will be (Bannink et al., 2008). The SCFA, being ruminal fermentation products, induce morpho-functional alterations in ruminal papillae (Gäbel et al., 1991a,b; Krehbiel et al., 1992; Nozière et al., 2000). Conversely, an increase of SCFA absorption in ruminants fed highconcentrate diets has been linked to the surface area enlargement of ruminal papillae (Dirksen et al., 1984; Gäbel et al., 1991a,b). The latter might be attributable to an increased abundance of gene transcripts related to epithelial proliferation (Penner et al., 2011).

The changes of morphology and function in ruminal papillae can be mainly attributed to butyrate (Krehbiel et al., 1992; Shen et al., 2005). It is produced in rumen at concentrations ranging from 9 to $15 \mathrm{~m} M$ (Bergman, 1990) and has the lowest concentration of the 3 main SCFA in rumen content (Plöger et al., 2012). Within the various short- and long-term effects of butyrate, its influence on epithelial morphology is the most strik- 
ing. Increases in its intraruminal concentration through supplementation with easily fermentable carbohydrates or by the exogenous addition of butyrate have been shown to increase epithelial proliferation (Sakata and Tamate, 1978) with subsequent increases in papillae size and surface area (Gäbel et al., 1987; Shen et al., 2005).

The proliferative effects of butyrate vary not only with the age and physiological status of the animals, but also with the dose, route, and rate of butyrate administration. Butyrate induces epithelial proliferation at high doses $(>2.5 \mathrm{~g} / \mathrm{kg}$ of BW per day) in young calves and starved adult sheep (Sakata and Tamate, 1978; Mentschel et al., 2001) and at low doses $(\leq 0.5 \mathrm{~g} /$ $\mathrm{kg}$ of BW per day) in fed cattle (Kauffold et al., 1977; Shen et al., 2005). Moreover, rapid infusion of butyrate induces proliferation, whereas slow infusion does not (Sakata and Tamate, 1976, 1978). Several recent reports have revealed that butyrate acts as a mitogenic factor and signaling molecule in the stimulation of cell proliferation in pigs, cattle, and humans in vivo (Kien et al., 2008; Hamer et al., 2008; Baldwin et al., 2012). In various cell culture models, however, butyrate inhibits proliferation, a result that has been linked either to the downregulation of cyclin D1 (Maier et al., 2009) or to the downregulation of the cyclin-dependent kinases (CDK) that overrule the concurrent increases in Dtype cyclins (Mathew et al., 2010). As D-type cyclins and their target kinases are responsible for $\mathrm{G}$ (gap) $)_{0} / \mathrm{G}_{1}$ to $\mathrm{S}$ (synthesis) phase progression, the downregulation of either could plausibly explain the antiproliferative effect of butyrate in vitro. Conversely, this raises the hypothesis that a proliferation-inducing effect of butyrate in vivo requires the prevention of the downregulation of D-type cyclins and of their target CDK. Therefore, the present study was aimed at investigating the changes in the expression of cyclin D1 (CCND1) and one of its major effector kinases, $C D K 4$, in relation to cell cycle progression in the transition of $\mathrm{G}_{0} / \mathrm{G}_{1}$ to $\mathrm{S}$ phase and to epithelial growth induced by daily ruminal butyrate infusions.

A significant amount of intraruminally produced SCFA are absorbed through carrier-mediated transport, which mainly involves 2 isoforms of the monocarboxylate transporter: MCT1 and MCT4 (Müller et al., 2002; Kirat et al., 2007). These isoforms are localized at the basolateral and luminal sides of the ruminal epithelium, respectively (Müller et al., 2002; Graham et al., 2007; Kirat et al., 2007), and are thought to play a role in the transportation of SCFA and their metabolites (Müller et al., 2002; Kirat et al., 2007). In the present study, we also examined the possible relevance of the butyrateinduced morphological changes to SCFA absorption and the possible changes in the transcription of SCFA transport proteins, namely monocarboxylate transporters MCT1 (MCT1 or SLC16A1) and MCT4 (MCT4 or $S L C 16 A 3)$ following ruminal butyrate infusions.

\section{MATERIALS AND METHODS}

Two experiments (Exp.) with a total of 23 goats were conducted. The experiments were approved by the Animal Care and Use Committee of Nanjing Agricultural University under the Act "The State Science and Technology Commission of P. R. China, 1988." All chemicals and reagents used in this study were purchased from Shanghai Shiye Chemical Reagent Co. Ltd. (Shanghai, China) unless otherwise stated.

\section{Experiment 1}

Animals, Feeding, and Infusion Procedure. Fifteen rumen-fistulated goats (Boer $\times$ Yangtze River Delta White) were used and were aged approximately 4 mo at the commencement of the experiment. The goats were randomly assigned into 2 groups: control $(\mathbf{C}, \mathrm{n}=$ 7) and butyrate-treated $(\mathbf{B}, \mathrm{n}=8)$. Concentrate $(200$ g) was provided to the goats of both groups in 2 equal portions at 0800 and $1700 \mathrm{~h}$ daily, and hay and water were provided ad libitum. The dietary components and their chemical composition are presented in Table 1. Goats in both groups received intraruminally one dose of $0.1 \mathrm{~mol} / \mathrm{L}$ potassium phosphate buffer $(50 \mathrm{~mL})$ without (C) or with (B) $0.3 \mathrm{~g} / \mathrm{kg}$ of BW per day of sodium n-butyrate (Merck, Hohenbrunn, Germany) at $0700 \mathrm{~h}$ daily; that is, $1 \mathrm{~h}$ before the morning feeding. The infusion was completed within 10 to $15 \mathrm{~s}$. After infusion, the rumen content was thoroughly mixed to ensure the uniform distribution of infusates throughout the rumen. Goats were weighed weekly to ensure accurate dose provision.

The experiment lasted for $28 \mathrm{~d}$. Feed was sampled at d 7 and 28 for chemical analysis. Dry matter content was determined by drying the feed at $105^{\circ} \mathrm{C}$ for $2 \mathrm{~h}$, and ash content was determined by combustion at $600^{\circ} \mathrm{C}$

Table 1. Chemical composition of diets fed to goats ${ }^{1}$

\begin{tabular}{lcc}
\hline Chemical & & \\
composition & Concentrate $^{1}$ & Hay \\
\hline DM (\%) & 87.75 & 89.81 \\
CP (\% of DM) & 20.89 & 7.32 \\
Crude fat (\% of DM) & 3.64 & 2.02 \\
Crude fiber (\% of DM) & 6.67 & 28.25 \\
Crude ash (\% of DM) & 7.73 & 6.4 \\
ME (MJ/kg of DM) & 10.85 & 6.96 \\
\hline
\end{tabular}

${ }^{1}$ The concentrate was composed of ground corn, soybean meal, cottonseed bran, wheat bran, fish meal, calcium phosphate, limestone, trace mineral salt, and vitamin premix (vitamins $\mathrm{A}, \mathrm{D}$, and $\mathrm{E}$ ). 
for at least $5 \mathrm{~h}$ (AOAC, 1990). Nitrogen content was determined by using flash combustion (Leco FR-528 analyzer; Leco, St. Joseph, MI), and CP content was calculated by multiplying the $\mathrm{N}$ concentration by 6.25 . Ether extract was determined by using a Goldfisch extraction apparatus (Labconco, Kansas City, MO; Rhee, 2005).

Sample Collection. Ruminal fluid (liquid digesta) samples were taken on d 14 just before infusion $(0 \mathrm{~h})$ and at $0.5,1.0,1.5,2.5$, and $3.5 \mathrm{~h}$ after infusion. Subsamples of ruminal fluid were collected in equal portions from the antrium ruminis, ventral rumen, caudal dorsal, and caudal ventral regions separately and then combined to form 1 sample. An aliquot $(20 \mathrm{~mL})$ of ruminal fluid was strained through a 4-layer gauze and immediately subjected to $\mathrm{pH}$ measurement. Thereafter, $5 \% \mathrm{HgCl}_{2}$ solution $(1 \mathrm{~mL})$ was added, and the sample was stored at $-20^{\circ} \mathrm{C}$. The goats were slaughtered at $8 \mathrm{~h}$ after butyrate infusion on d 28. Immediately after slaughter, the goat abdomen was opened, and the stomachs were exteriorized. The rumen was separated from the omasum and washed with PBS. Thereafter, the empty rumen weight was recorded. Ruminal tissues (about $2 \mathrm{~cm}^{2}$ ) from the atrium ruminis, ventral rumen sac, and ventral blind sac were fixed in $4 \%$ paraformaldehyde solution to analyze morphology and size of papillae. Additional tissue samples from the same locations ( $10 \mathrm{~g}$ each) were transferred into liquid nitrogen after detachment from the muscle layers and stored at $-80^{\circ} \mathrm{C}$ until molecular biological analyses. A third sample $\left(1 \mathrm{~cm}^{2}\right)$ from the atrium ruminis, ventral rumen, and ventral blind sac was collected and stored in cold PBS to measure papillae density. A fourth sample was taken from the ventral rumen $\left(5 \mathrm{~cm}^{2}\right)$ and peeled off from the underlying musculature to determine the epithelium weight. Finally, the remainder of the rumen tissue was immediately rinsed, soaked in Hanks' balanced salt solution, and transferred to the laboratory, and a portion of rumen tissue $(10 \mathrm{~g})$ was used for cell cycle analysis.

Morphometric and Histomorphometric Analyses. A piece of ruminal tissue, $1 \mathrm{~cm}^{2}$, from the atrium ruminis, ventral rumen, and ventral blind sac was rinsed in PBS and the papillae were cut and counted (density, number $/ \mathrm{cm}^{2}$ ). The length and width of the ruminal papillae were measured directly on paraformaldehydefixed papillae by using a sliding caliper. Fifteen papillae in each of the samples of atrium ruminis, ventral rumen sac, and ventral blind sac were measured for each goat in groups B and C. The mucosa surface $\left(\mathrm{mm}^{2} / \mathrm{cm}^{2}\right)$ was determined as the length $\times$ width $\times$ density $\times 2$. Tissue samples from the atrium ruminis of 6 goats in each group were used to evaluate the histomorphology. Samples were fixed in $4 \%$ paraformaldehyde overnight, dehydrated, cleared, and embedded in paraffin. Sections of 5 to $7 \mu \mathrm{m}$ in thickness were cut and stained by the standard hematoxylin and eosin (H\&E) procedure. The ruminal tissue $\left(1 \mathrm{~cm}^{2}\right.$ /goat) selected for histomorphological analysis contained papillae with almost identical shape and size. For each tissue, 25 to 30 papillae were embedded for paraffin-sectioning and microscopic observation. From these, the 4 paraffin sections with the best orientation of papillae in the median sagittal plane were used to evaluate the morphological characteristics of the ruminal papillae by using Image-Pro Plus 6.0 (Media Cybernetics Inc., Bethesda, MD).

The number of cell layers forming the stratum corneum (SC) and stratum germinativum (SGv) were counted, the latter consisting of the stratum granulosum (SG) and stratum spinosum (SS). Epithelial cell density (number $/ \mathrm{mm}^{2}$ ) was measured in $\mathrm{SGv}$ and in the stratum basale (SB).

Cell Isolation and Flow Cytometry Assay. Cells were isolated from rumen epithelial tissue $(10 \mathrm{~g}$ of wet weight, sampled from the antrium ruminis) by the serial trypsin digestion method (Baldwin, 1999). Isolated cells were fixed in ethanol (75\%), washed, and treated with RNase solution (100 U/mL in PBS, $\left.37^{\circ} \mathrm{C}, 30 \mathrm{~min}\right)$, followed by incubation with propidium iodide $(70 \mathrm{mM}$ in PBS) for 30 min and analysis on a BD FACScan Flow Cytometer (BD Biosciences, San Jose, CA). The cell cycle was analyzed by a computer-aided Multicycle Program (Phoenix, San Diego, CA).

Determination of Ruminal SCFA Concentrations. Ruminal SCFA concentrations were determined by a chromatograph HP6890N (Agilent Technologies, Wilmington, DE) as described by Yang et al. (2012). Nitrogen (99.99\% purity) was used as the carrier gas with a constant flow rate of $2.8 \mathrm{~mL} / \mathrm{min}$ and a split ratio of 1:30. The capillary column temperature was set to $140^{\circ} \mathrm{C}$ for $4 \mathrm{~min}$ and then increased at $25^{\circ} \mathrm{C} /$ min to $240^{\circ} \mathrm{C}$. The temperatures of the injection port and the flame-ionization detector were set to $180^{\circ} \mathrm{C}$ and $250^{\circ} \mathrm{C}$, respectively. Tiglic acid $\left(\mathrm{C}_{5} \mathrm{H}_{8} \mathrm{O}_{2}\right)$ was used as an internal standard. For the purpose of this study, the term "total SCFA concentration" represents the sum of acetate, propionate, and butyrate concentrations.

Ruminal SCFA Passage and Absorption. Passage and absorption of SCFA from the rumen was estimated in 8 goats ( $\mathrm{n}=4$ in each group) on $\mathrm{d} 26$ by the H-Val-Co method, in which Co-EDTA was used as a fluid passage marker and $n$-valeric acid as an indicator of SCFA clearance from the rumen (Udén et al., 1980; Resende Júnior et al., 2006; Penner et al., 2009). Ruminal butyrate infusions were suspended on that day so as not to interfere with the absorption measurements. Moreover, to minimize fluctuations in baseline valeric acid concentration, goats were provided with their feed 
in 3 equal proportions at 1300, 2100, and $0500 \mathrm{~h}$ starting the day before the marker dose. Each goat received a single dose of $32 \mathrm{~mL}$ of a solution containing $12 \mathrm{~g}$ of $n$-valeric acid and $167.5 \mathrm{mg}$ of Co-EDTA buffered to $\mathrm{pH} 6.8$ with $\mathrm{NaOH}$ at $0800 \mathrm{~h}$ on d 26. The CoEDTA/ $n$-valeric acid solution was thoroughly mixed into the ruminal contents. An initial sample was collected immediately before the marker dose (time 0), and subsequent ruminal fluid samples were collected at $0.25,0.5,1,2,3,6,12,18$, and $24 \mathrm{~h}$ after the dose. Individual samples of ruminal fluid were analyzed for valeric acid and Co concentrations. The intraruminal Co concentration was determined by atomic absorption spectrometry (Perkin Elmer Optima 2100 DV, PerkinElmer Life and Analytical Sciences, Shelton, CT), and valerate was determined by gas chromatography as described in the previous section. The exponential rate of decay for Co and $n$-valeric acid were calculated as previously described (Resende Júnior et al., 2006; Penner et al., 2009) by using the equation: $R_{t}=R_{0}$ $\times \mathrm{e}^{-k \times t}$, where $\mathrm{R}_{\mathrm{t}}=$ concentration at a given time, $\mathrm{R}_{0}=$ concentration at time $0, k=$ fractional rate of clearance, and $t=$ time in $\mathrm{h}$. To calculate the fractional rate of SCFA absorption, the rate of Co clearance was subtracted from the rate of $\mathrm{n}$-valeric acid clearance.

Total RNA Extraction, cDNA Synthesis, and Quantitative Real-Time PCR. Total RNA was extracted from homogenized ruminal tissue (sampled from atrium ruminis) by using the acid guanidinium thiocyanate-phenol-chloroform (GTC) method, as described by Chomczynski and Sacchi (2006). The RNA concentration and purity were assessed from extinction measurements at 260 and $280 \mathrm{~nm}$ in a Biophotometer (Eppendorf, Hamburg, Germany). All samples had an absorbance ratio (260:280) between 1.91 and 2.29, indicating high RNA purity. The samples were then adjusted to an RNA concentration of $1 \mu \mathrm{g} / \mu \mathrm{L}$. Random hexamer primer (Invitrogen, Shanghai, China) and M-MLV (Moloney murine leukemia virus) reverse transcriptase (Fermentas, Burlington, ON, Canada) were used to synthesize cDNA. Determination of relative mRNA expression was performed with real-time PCR by using the MyiQ2 2-color real-time PCR detection system (Bio-Rad Laboratories Inc., Hercules, CA). Real-time PCR was carried out in a total volume of 20 $\mu \mathrm{L}$ containing $1 \times \mathrm{iQ}$ SYBR Green supermix (Bio-Rad Laboratories), a mixture of forward and reverse primers (Table 2), cDNA template, and sterile water for volume adjustment. An initial cycle of $30 \mathrm{~s}$ at $95^{\circ} \mathrm{C}$ was used to denature the cDNA. This was followed with 40 PCR cycles consisting of denaturation at $95^{\circ} \mathrm{C}$ for $10 \mathrm{~s}$ and primer annealing and extension at $55^{\circ} \mathrm{C}$ for $30 \mathrm{~s}$. Before performing PCR for experimental samples, we calculated the amplification efficiencies of all primers by using a standard dilution series. After each PCR, a melt curve analysis was carried out. All samples were analyzed in triplicate. Gene expression was normalized to $18 S R N A\left(\Delta \mathrm{Ct}=\mathrm{Ct}_{\text {target }}-\mathrm{Ct}_{18 \mathrm{~S}}\right)$, where $\mathrm{Ct}=$ cycle threshold. The relative expression values were calculated by using the formula $\left(2^{-\Delta \Delta \mathrm{Ct}}\right)$ as described by Livak and Schmittgen (2001).

\section{Experiment 2}

Experiment 2 was performed exclusively to conduct a time-course analysis of gene expression by using only 1 group of 8 ruminally fistulated goats subjected to daily butyrate infusions. The age and feeding of goats and the infusion protocol were as described for Exp. 1. At variance to Exp. 1, samples of the ruminal epithelium were taken by biopsy at 3 time points: preinfusion $(0 \mathrm{~h})$, and 3 and $7 \mathrm{~h}$ postinfusion on d 28. Biopsy samples were taken from the atrium ruminis, immediately cleaned in PBS, and transferred to liquid nitrogen for storage at $-80^{\circ} \mathrm{C}$ until analyzed for mRNA expression (as above).

\section{Statistical Analysis}

Data (means \pm SEM) were analyzed by using statistical software SPSS12.0 (StatSoft, Tulsa, OK), and the differences were considered significant at $P<0.05$.

Table 2. Primers used for quantitative real-time PCR analysis

\begin{tabular}{|c|c|c|c|}
\hline Gene $^{1}$ & Primer sequence ( $5^{\prime}$ to $3^{\prime}$; forward, reverse) & Reference & Size (bp) \\
\hline $18 S r R N A$ & $\begin{array}{l}\text { GAAACGGCTACCACATCC } \\
\text { GCCAGACTTGCCCTCC }\end{array}$ & DQ222453 & 167 \\
\hline$C C N D 1$ & $\begin{array}{l}\text { GGTCCTGGTGAACAAACTC } \\
\text { TTGCGGATGATCTGCTT }\end{array}$ & EU525165.1 & 114 \\
\hline$C D K 4$ & $\begin{array}{l}\text { TGAGCATCCCAATGTTGT } \\
\text { CCTTGTCCAGATACGTCCT }\end{array}$ & NM_001127269.1 & 122 \\
\hline$M C T 1$ & $\begin{array}{l}\text { ACCAGTTTTAGGTCGTCTCA } \\
\text { GGCTTCTCAGCAACATCTACA }\end{array}$ & XM_004002335.1 & 207 \\
\hline$M C T 4$ & $\begin{array}{l}\text { GTTTGGGATAGGCTACAGTGACACA } \\
\text { GCAGCCAAAGCGATTCACA }\end{array}$ & NM_001109980.1 & 106 \\
\hline
\end{tabular}

${ }^{1} 18 S r R N A=18 \mathrm{~S}$ ribosomal RNA; $C C N D 1=$ cyclin D1; CDK4 = cyclin-dependent kinase $4 ; M C T 1=$ monocarboxylic acid transporter 1 (solute carrier family 16, member $1 ; S L C 16 A 1$ ); MCT4 = monocarboxylic acid transporter 4 (solute carrier family 16, member $3 ;$ SLC16A3). 
Data for papillae morphology and mRNA expression between 2 groups were compared by the conventional Student's t-test. The GLM procedure for repeated measures (between-subjects model) was used for SCFA concentrations and $\mathrm{pH}$ variables over time between 2 groups and, if the $F$-value was significant, then the Student-Newman-Keul's post hoc test was applied to determine the significance between time points. To analyze mRNA expression, normalized quantitative PCR (qPCR) data were transformed to obtain a mean of 1.0 at time 0 h. For the time course effect, normalized qPCR data were presented as the fold-change relative to the first baseline measurement (time 0) and were subsequently analyzed by the GLM procedure with repeated measures (within-subject model) to determine significance.

\section{RESULTS}

\section{Ruminal Fermentation}

Figure 1 shows the effect of ruminal butyrate infusion on the molar concentration of SCFA, the molar proportional concentrations of acetate, propionate, and butyrate, the acetate:propionate ratio, and the $\mathrm{pH}$ in the ruminal fluid. Before butyrate infusion, the concentration of SCFA did not differ between groups B and C. At 0.5 and $1 \mathrm{~h}$ after ruminal butyrate infusion, the SCFA concentrations tended to be higher in group B than in group $\mathrm{C}$ but, thereafter, no differences in SCFA concentration were seen between the groups at the indicated time points $(P>0.05)$. In group $\mathrm{B}$, the molar proportional concentration of butyrate increased $(P<$ 0.05 ) by about $100 \%$, compared with the preinfusion level, and remained elevated for $1.5 \mathrm{~h}$. It subsequently decreased gradually and almost returned to its preinfusion level within $2.5 \mathrm{~h}$. In group C, the molar proportional concentration of butyrate remained unchanged over the time points. Compared with $0 \mathrm{~h}$, the molar proportional concentrations of acetate and propionate were lower $(P<0.05)$ at 0.5 and $1 \mathrm{~h}$ after infusion and then gradually returned to their preinfusion values. The ruminal fluid $\mathrm{pH}$ and acetate:propionate ratio did not differ between the groups.

\section{Papillae Morphology and Rumen Epithelial Growth}

The papillae length, width, and density in the atrium ruminis and ventral rumen increased in group B compared with group $\mathrm{C}(P<0.05$; Table 3$)$. In the ventral blind sac, the length and width of papillae increased $(P$ $<0.05)$, and the density tended to increase $(P=0.07)$ in B compared with $\mathrm{C}$. The increases in papillae length, width, and density led to an increase in the surface area of these 3 regions in $\mathrm{B}$ compared with $\mathrm{C}(P<0.01$; Table 3 ). The empty rumen organ weight, expressed as a percentage of empty BW $(P<0.05)$, and the rumen epithelial weight $(P=0.05)$ were greater in $\mathrm{B}$ than in C (Table 4). The number of cell layers forming SC in the atrium ruminis was not different between groups $\mathrm{B}$ and $\mathrm{C}$. However, the number of cell layers in SGv $(P<0.05)$ and the cell densities in SGv and SB $(P<$ 0.05) were higher in $\mathrm{B}$ than in $\mathrm{C}$ (Table 4). In Figure 2 , the micrographs and histomicrographs showed that the length (a) and thickness (b) of the rumen papillae were larger in B than in C (Figure 2, panel I and panel II). Histomicrographs additionally showed that the thickness of the epithelium (c) was greater in group B compared with that in group C (Figure 2, panel II); and the cell layer number in epithelial strata (d and e) was higher in group B compared with that in group C (Figure 2, panel III).

\section{Analyses of Cell Cycle and Gene Expression}

In Exp. 1, the proportion of cell numbers in the $\mathrm{G}_{0} /$ $\mathrm{G}_{1}$ phases of the cell cycle tended to be reduced $(P=$ 0.065 ) in B compared with $\mathrm{C}$ (Table 5). However, the mRNA expression level of CCND1 and CDK4 in the ruminal epithelium did not differ between the groups $(P>0.05$; Figure 3, panel a). The analyses of monocarboxylate transporter genes showed that the mRNA expression of $M C T 4$, but not $M C T 1$, increased in group B compared with $\mathrm{C}(P<0.05$, Figure 3 , panel b).

In Exp. 2, the mRNA expression of CCND1 increased at $3 \mathrm{~h}$ after infusion compared with the preinfusion value $(P<0.05)$ and then returned to preinfusion values at $7 \mathrm{~h}$ after infusion (Figure 4 ). The mRNA expression of $C D K 4$ remained unchanged between the time points $(P>0.05$, Figure 4). The mRNA expression levels of $M C T 1$ and MCT4 were not changed between the time points $(P>0.05$, Figure 4$)$.

\section{Passage and Absorption of SCFA from Rumen}

On d 26 of Exp. 1, butyrate infusions were suspended to measure SCFA absorption by the H-Val-Co method. The molar concentrations of Co and valeric acid in the ruminal fluid showed peaked at 30 min after marker infusion and then linearly decreased with time (data not shown). The molar concentration of total SCFA, $\mathrm{pH}$, and the molar proportions of individual SCFA in the ruminal fluid were not different between groups $(P$ $>0.05$; Figure 5). The estimated fractional rate $(\% / \mathrm{h})$ of SCFA passage from the rumen did not differ between the groups $(P>0.05)$; however, the fractional rate $(\% / \mathrm{h})$ of SCFA absorption increased $(P<0.05)$ in B compared with C (Table 6). 

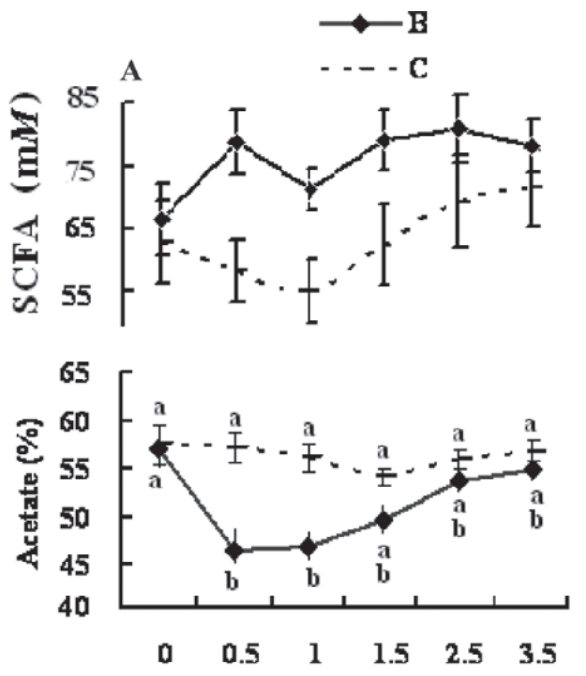

B
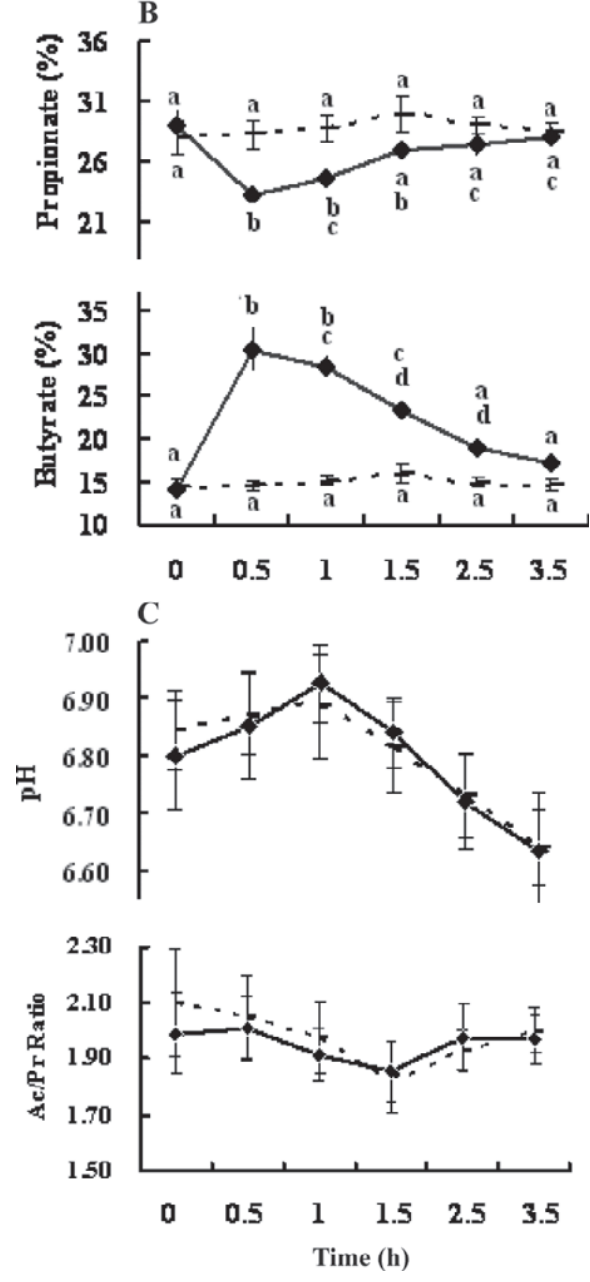

Figure 1. Effect of ruminal butyrate infusion on the molar concentration of short-chain fatty acids (SCFA; acetate, propionate, and butyrate), and their molar proportional concentrations, the acetate:propionate $(\mathrm{Ac} / \mathrm{Pr})$ ratio, and the $\mathrm{pH}$ in the ruminal fluid of goats. At $t=0 \mathrm{~h}$, goats received infusion of $0.1 \mathrm{M}$ potassium phosphate buffer $(50 \mathrm{~mL})$ containing sodium butyrate at $0.3(\mathrm{~B}, \mathrm{n}=8)$ or $0(\mathrm{C}, \mathrm{n}=7) \mathrm{g} / \mathrm{kg}$ of $\mathrm{BW}$ per day over $28 \mathrm{~d}$ in experiment 1 . Values (means $\pm \mathrm{SE}$ ) differ if they do not share a common letter: ${ }^{\mathrm{a} d} \mathrm{P}<0.05$.

\section{DISCUSSION}

\section{Ruminal Butyrate Infusion, Papillae Morphology, and Epithelial Growth}

Previous studies have shown that the effects of exogenous butyrate on rumen epithelial proliferation are influenced by the method of administration. Sakata and Tamate (1978) administered an equal dose of butyrate into the rumen of starved sheep by rapid infusion within $10 \mathrm{~s}$ or by continuous infusion lasting for $24 \mathrm{~h}$. The rapid infusion increased rumen epithelial mitotic indices, but the continuous infusion did not. The dosage used in the above experiment was $2 \mathrm{~g} / \mathrm{kg}$ of BW per day. This high amount of butyrate loading can be expected to elevate the ruminal butyrate concentration to $100 \mathrm{~m} M$ within 5 min after infusion (Neogrády et al., 1989), which is 5 to 15 times higher than the normal butyrate concentration (6 to $17 \mathrm{~m} M$ ) in the rumen of sheep (Gäbel et al., 1987). In contrast, in starved animals, butyrate at a dose rate of $2 \mathrm{~g} / \mathrm{kg}$ of $\mathrm{BW}$ per day administered either by continuous or by rapid intraruminal infusion for $9 \mathrm{~d}$ in normally fed calves did not induce epithelial growth, except for the thickening of the stratum corneum (Galfi et al., 1986). Ohwada and Tamate (1989) have observed that butyrate at a dose of $1 \mathrm{~g} / \mathrm{kg}$ of BW per day caused an increase in butyrate concentration above the physiological limits in the rumen of sheep. This high dose of butyrate decreased the number of dividing cells at $1 \mathrm{~h}$ after infusion. Gäbel et al. (2002) have suggested that the elevated ruminal butyrate concentration promotes differentiation and stops cell proliferation. On the other hand, short-term infusion of butyrate into the fed rumen at lower doses, such as $0.5 \mathrm{~g} / \mathrm{kg}$ of $\mathrm{BW}$ per day (Shen et al., 2005) or $0.3 \mathrm{~g} / \mathrm{kg}$ of BW per day (Kauffold et al., 1977), stimulated epithelial proliferation in cattle. These data indicate that the efficient stimulation of rumen epithelial proliferation needs a relevant concentration of butyrate, which can be supplied either by rapid loading of butyrate into the starved rumen or by continuous loading into the fed rumen.

In the present study, butyrate was infused rapidly at a rate of $0.3 \mathrm{~g} / \mathrm{kg}$ of $\mathrm{BW}$ per day into the rumen at $1 \mathrm{~h}$ before the morning feeding. The ruminal molar proportional concentration of butyrate increased $30 \mathrm{~min}$ after infusion; that is, at the first postinfusion measurement, and remained elevated for at least $1.5 \mathrm{~h}$. Accordingly, the molar proportional concentrations of acetate and propionate were reduced at 0.5 and $1 \mathrm{~h}$ after infusion, compared with $0 \mathrm{~h}$. A similar reduction of molar concentrations of acetate and propionate was observed after the intraruminal administration of butyrate in cattle (Huhtanen et al., 1993; Shen et al., 2005). The peak concentration of butyrate in the present study (24 
Table 3. Effects of ruminal butyrate infusion on papillae morphology in various regions of the rumen of goats ${ }^{1}$

\begin{tabular}{|c|c|c|c|}
\hline \multirow[b]{2}{*}{ Item } & \multicolumn{2}{|c|}{ Group } & \multirow[b]{2}{*}{$P$-value } \\
\hline & B & $\mathrm{C}$ & \\
\hline \multicolumn{4}{|l|}{ Atrium ruminis } \\
\hline Length (mm) & $5.7 \pm 0.21$ & $4.6 \pm 0.10$ & 0.001 \\
\hline Width (mm) & $2.0 \pm 0.14$ & $1.5 \pm 0.04$ & 0.015 \\
\hline Density $\left(\mathrm{no} . / \mathrm{cm}^{2}\right)$ & $78 \pm 1$ & $68 \pm 1$ & 0.001 \\
\hline Surface $\left(\mathrm{mm}^{2} / \mathrm{cm}^{2}\right)$ & $1,822 \pm 179$ & $957 \pm 55$ & 0.004 \\
\hline \multicolumn{4}{|l|}{ Ventral rumen } \\
\hline Length (mm) & $4.4 \pm 0.27$ & $3.5 \pm 0.16$ & 0.011 \\
\hline Width (mm) & $1.8 \pm 0.08$ & $1.5 \pm 0.06$ & 0.009 \\
\hline Density $\left(\right.$ no. $\left./ \mathrm{cm}^{2}\right)$ & $84 \pm 4$ & $73 \pm 3$ & 0.049 \\
\hline Surface $\left(\mathrm{mm}^{2} / \mathrm{cm}^{2}\right)$ & $1,350 \pm 160$ & $753 \pm 87$ & 0.009 \\
\hline \multicolumn{4}{|l|}{ Ventral blind sac } \\
\hline Length (mm) & $3.3 \pm 0.15$ & $2.6 \pm 0.17$ & 0.013 \\
\hline Width (mm) & $1.8 \pm 0.03$ & $1.5 \pm 0.05$ & 0.009 \\
\hline Density $\left(\right.$ no. $\left./ \mathrm{cm}^{2}\right)$ & $90 \pm 5$ & $77 \pm 5$ & 0.072 \\
\hline Surface $\left(\mathrm{mm}^{2} / \mathrm{cm}^{2}\right)$ & $1,060 \pm 89$ & $601 \pm 70$ & 0.002 \\
\hline
\end{tabular}

${ }^{1}$ Goats were infused with sodium butyrate at $0.3(\mathrm{~B}, \mathrm{n}=8)$ or $0(\mathrm{C}, \mathrm{n}=7) \mathrm{g} / \mathrm{kg}$ of BW per day in $0.1 \mathrm{M}$ potassium buffer $(50 \mathrm{~mL})$ over $28 \mathrm{~d}$ (experiment 1). Rumen papillae samples from 6 goats of each group were used for morphological evaluation. Values are means \pm standard error.

$\mathrm{m} M$; data not shown) at 30 min after the infusion was within the normal physiological range (Nozière et al., 2000) and representative of the high ruminal butyrate production in ruminants supplemented with easily fermentable diets (Gäbel et al., 1987). The butyrate concentration was about $110 \%$ higher in group B than in the control group. The acetate:propionate ratio did not change, suggesting that the amount of butyrate infused did not change the fermentation pattern of the basal diet (Huhtanen et al., 1993).

Previous studies have shown that an increase in the proportion of ruminal butyrate is associated with an increase in ruminal mass (Shen et al., 2004; Yang et al., 2012). Dietary supplementation of butyrate $(0.3 \% / \mathrm{kg}$ of DM) for 3 wk also increases ruminal weight in suckling calves (Gorka et al., 2009). In the present study, the reticuloruminal weight, expressed as a percentage of BW, was greater in group B than in group C. The ruminal epithelium is the functionally important part of the rumen, transporting the nutrients, mainly SCFA, from the rumen to the blood (Krehbiel et al., 1992; Nozière et al., 2000; Kristensen and Harmon, 2004). It makes up 40 to $60 \%$ of total ruminal weight, and the epithelial proportional weight increases with higher SCFA concentrations (Baldwin, 2000; Bannink et al., 2008). Among the 3 SCFA, butyrate has the strongest stimulatory effect on epithelial growth (Sander et al., 1959; Kauffold et al., 1977). In the present study, the size, density, and surface area of papillae increased in all 3 tested ruminal regions. Papillae length and width were increased by approximately $25 \%$ and density by $15 \%$ in the atrium ruminis, ventral rumen, and ventral blind sac. Greater length and width of papillae in the atrium ruminis have been shown in castrated

Table 4. Effects of ruminal butyrate infusion on ruminal weight, rumen epithelial weight, and histometric characteristics of ruminal epithelium of goats $^{1}$

\begin{tabular}{lccc}
\hline & \multicolumn{2}{c}{ Group } & \\
\cline { 2 - 3 } Item & $\mathrm{B}$ & $\mathrm{C}$ & $P$-value \\
\hline Ruminal weight $(\%$ of empty BW) & $2.74 \pm 0.10$ & $2.41 \pm 0.08$ & 0.034 \\
Rumen epithelial weight $\left(\mathrm{g} / 5 \mathrm{~cm}^{2}\right)$ & $6.51 \pm 0.16$ & $5.82 \pm 0.18$ & 0.016 \\
Thickness of epithelial strata & & & \\
(no. of cell layers) & $5.25 \pm 0.25$ & $4.25 \pm 0.25$ & 0.030 \\
$\quad$ Stratum germinativum & $3.50 \pm 0.29$ & $2.75 \pm 0.25$ & 0.097 \\
$\quad$ Stratum corneum & $7,015 \pm 295$ & $5,905 \pm 231$ & 0.025 \\
Cell density in epithelial strata $\left(\right.$ no./ $\left./ \mathrm{mm}^{2}\right)$ & $273 \pm 13$ & $226 \pm 4$ & 0.016 \\
$\quad$ Stratum germinativum & & \\
Stratum basale & &
\end{tabular}

${ }^{1}$ Goats were infused with sodium butyrate at $0.3(\mathrm{~B}, \mathrm{n}=8)$ or $0(\mathrm{C}, \mathrm{n}=7) \mathrm{g} / \mathrm{kg}$ of BW per day in $0.1 M$ potassium buffer $(50 \mathrm{~mL})$ over $28 \mathrm{~d}$ (experiment 1). Rumen papillae samples for histomorphometry were collected from the atrium ruminis of 6 goats of each group. Values are means \pm standard error. 


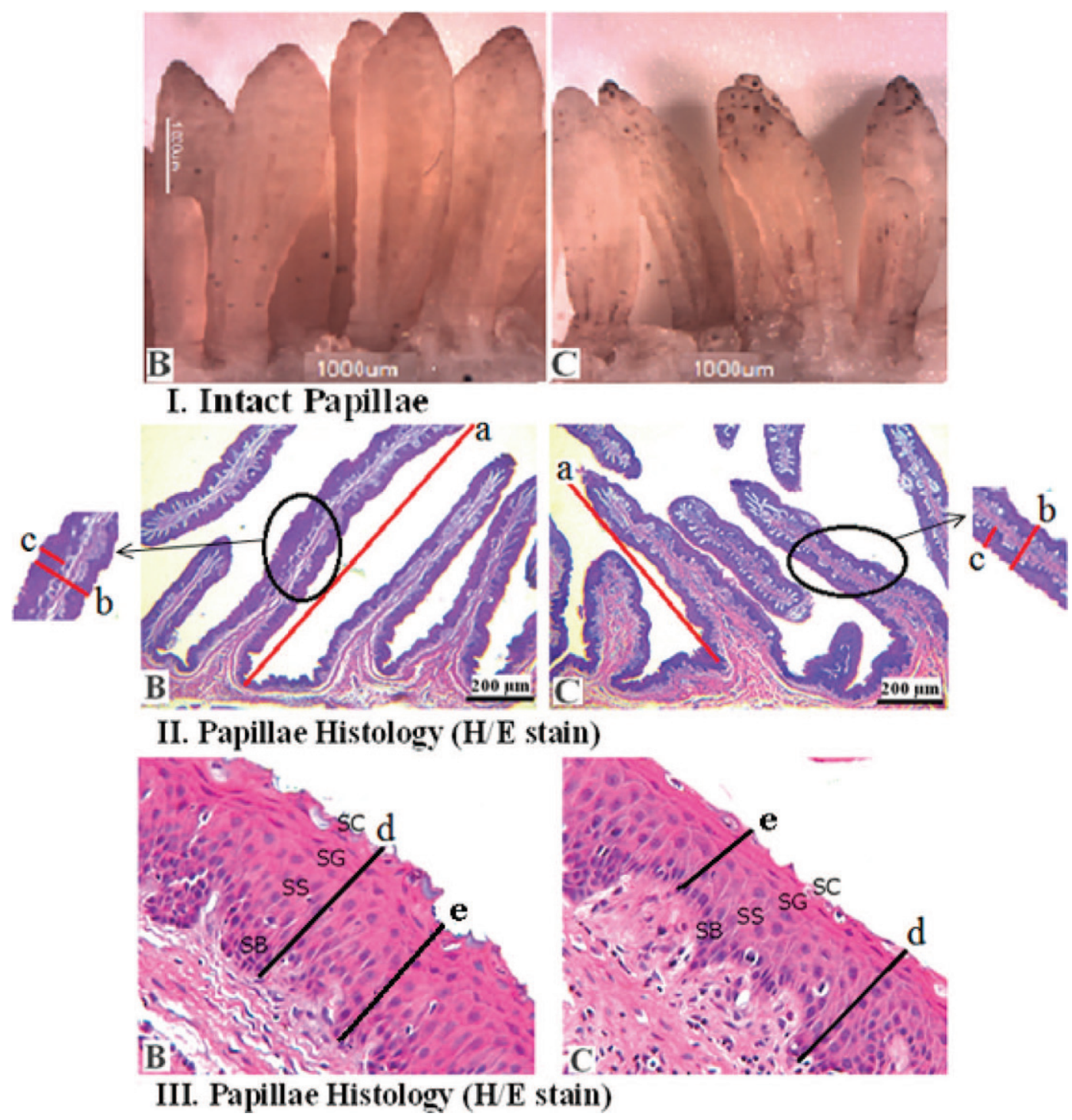

Figure 2. Micrographs (I) showing length and width of rumen papillae; histomicrographs (II) showing length (a) and thickness of papilla (b), and thickness of epithelium (c); and epithelial strata (III) at maximum (d) and minimum (e) depths in epithelium of goats. Goats were infused with $0.1 M$ potassium phosphate buffer $(50 \mathrm{~mL})$ containing sodium butyrate at $0.3(\mathrm{~B}, \mathrm{n}=8)$ or $0(\mathrm{C}, \mathrm{n}=7) \mathrm{g} / \mathrm{kg}$ of $\mathrm{BW}$ per day over $28 \mathrm{~d}$ in experiment $1 . \mathrm{H} / \mathrm{E}=$ hematoxylin and eosin. $\mathrm{SB}=$ stratum basale; $\mathrm{SS}=$ stratum spinosum; $\mathrm{SG}=$ stratum granulosum; $\mathrm{SC}=$ stratum corneum. Color version available in the online PDF.

bulls receiving daily short-term intraruminal infusion of butyrate at a dose of $0.5 \mathrm{~g} / \mathrm{kg}$ of BW per day (Shen et al., 2005) and in young calves that received a dietary supply of butyrate at a dose of $0.3 \%$ of DM (Gorka et al., 2009). Mentschel et al. (2001) found a higher length and width of papillae sampled from the atrium ruminis and ventral ruminal regions in calves when a butyrate supplement $(\sim 3 \mathrm{~g} / \mathrm{kg}$ of BW per day) was added to a basal diet for 6 wk. The overall increase in papillae dimensions (length and width) and density in the present study led to an increase in surface area ranging between 76 and $90 \%$ in all 3 analyzed rumen regions of goats in group B. Further histomorphometric analysis revealed a larger number of cells and cell layers forming the lower epithelial strata; this caused an increase in the total thickness of the ruminal epithelium in the goats of group B compared with those of group C. Similar histological changes were observed in the ruminal epithelium of cattle that had received butyrate treatment (Kauffold et al., 1977; Mentschel et al., 2001).

The SB is a single-celled layer that is considered to contain stem cells and progenitors of actively dividing cells. Increased proliferation, shown by the counting of dividing cells in the basal layer of epithelium, has been reported in calves fed a butyrate-supplemented diet (Mentschel et al., 2001) and in adult sheep receiving 
intraruminal infusions of butyrate (Sakata and Tamate, 1978). In the present study, the higher density of SB in group B indicated that the rate of cell proliferation had increased.

\section{Rumen Epithelial Proliferation and Expression of Related Genes}

From the presented data and the discussion in the previous sections, we conclude that the chosen experimental protocol is highly appropriate for modeling the changes in epithelial morphology that occur via butyrate production when feeding ruminants high-energy diets. One main aim of the present study was to provide insight into the cellular and molecular mechanisms behind this epitheliotrophic effect.

Cellular proliferation is controlled primarily by the regulation of the cell cycle, which consists of 4 distinct
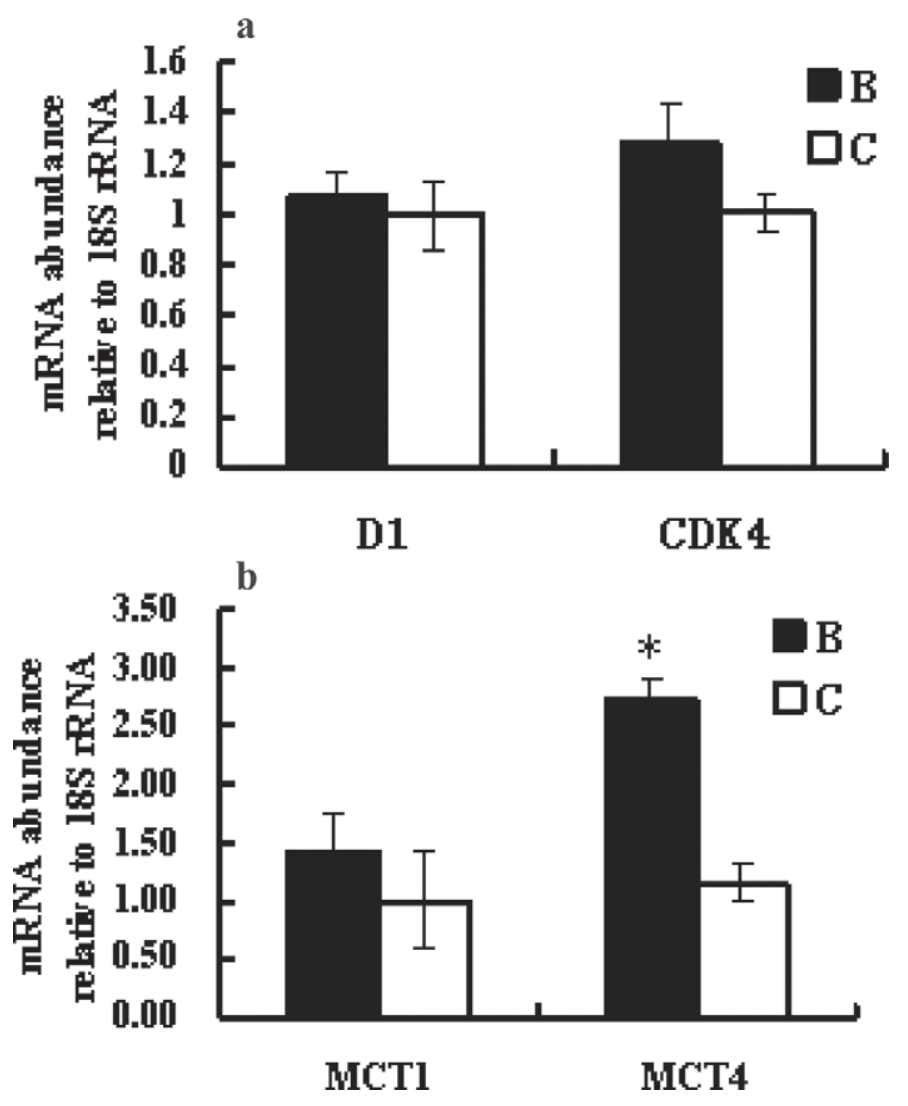

Figure 3. Effect of ruminal butyrate infusion on the mRNA expression of cyclin D1 (CCND1) and cyclin-dependent kinase 4 (CDK4; a) and of monocarboxylase transporter MCT1 and MCT4 (b) in the ruminal epithelium of goats. Expression was normalized to $18 S \mathrm{rRNA}$. Goats were infused with $0.1 M$ potassium phosphate buffer $(50 \mathrm{~mL})$ containing sodium butyrate at $0.3(\mathrm{~B}, \mathrm{n}=8)$ or $0(\mathrm{C}, \mathrm{n}=7) \mathrm{g} / \mathrm{kg}$ of BW per day over $28 \mathrm{~d}$ and slaughtered $8 \mathrm{~h}$ after the last infusion (experiment 1). Values are means $\pm \mathrm{SE} ;{ }^{*}=$ differences from $\mathrm{C}$ with $P<0.05$.
Table 5. Effects of ruminal butyrate on cell cycle progression in ruminal epithelium of goats

\begin{tabular}{lrcc}
\hline & \multicolumn{2}{c}{ Group } & \\
\cline { 2 - 3 } Cell cycle $^{2}$ & \multicolumn{1}{c}{$\mathrm{B}$} & $\mathrm{C}$ & $P$-value \\
\hline $\mathrm{G}_{0} / \mathrm{G}_{1}(\%)$ & $75.6 \pm 1.9$ & $81.1 \pm 1.9$ & 0.065 \\
$\mathrm{~S}(\%)$ & $15.2 \pm 4.2$ & $9.1 \pm 3.1$ & 0.27 \\
$\mathrm{G}_{2} \mathrm{M}(\%)$ & $9.2 \pm 3.5$ & $9.8 \pm 3.3$ & 0.91 \\
\hline
\end{tabular}

${ }^{1}$ Goats were infused with sodium butyrate at $0.3(\mathrm{~B}, \mathrm{n}=8)$ or $0(\mathrm{C}, \mathrm{n}$ $=7) \mathrm{g} / \mathrm{kg}$ of BW per day in $0.1 \mathrm{M}$ potassium buffer $(50 \mathrm{~mL})$ over 28 d (experiment 1). Samples from 6 goats of each group were used for flow-cytometric analysis. Values are means \pm standard error.

${ }^{2} \mathrm{G}_{0} / \mathrm{G}_{1}=$ the proportion of cells in the gap $(\mathrm{G})_{0}$ phase and $\mathrm{G}_{1}$ phase (the percentage is based on 10,000 cells) ; $\mathrm{S}=$ the proportion of cells in the synthesis $(\mathrm{S})$ phase, based on the fact that the single-cell DNA level is higher than the DNA content of resting diploid cells (the percentage is based on 10,000 cells measured); $\mathrm{G}_{2} \mathrm{M}=$ the proportion of mitotic cells (the percentage is based on 10,000 cells).

but sequential phases $\left(\mathrm{G}_{1}, \mathrm{~S}, \mathrm{G}_{2}\right.$, and $\mathrm{M}$ phase); any change in the duration of one or more phases of the cell cycle will affect the rate of cell production (Shen et al., 2004). Cells in S phase are characterized by the presence of double the amount of nuclear material (DNA synthesis) and are reported to increase in bulls receiving intraruminal butyrate infusion, suggesting an increased transition from $\mathrm{G}_{1}$ to $\mathrm{S}$ phase (Shen et al., 2005). In group $B$ of the present study, the tendency for a decreasing cellular fraction in $\mathrm{G}_{0} / \mathrm{G}_{1}$ phase and a numerical increase in the cell fraction in $\mathrm{S}$ phase indicated that butyrate infusion also promoted the progression from $\mathrm{G}_{0} / \mathrm{G}_{1}$ to $\mathrm{S}$ phase.

The cell cycle regulating proteins, namely cyclin D1 and cyclin-dependent kinase type 4, are the key regulators for promoting the transition from $\mathrm{G}_{0} / \mathrm{G}_{1}$ to $\mathrm{S}$ phase. Cyclin D1 binds with CDK4 to form a complex that promotes the cells across the "checkpoint" of $\mathrm{G}_{1}$ phase to enter the S phase (Mathew et al., 2010). Butyrate has been shown to decrease cyclin D1 levels and proliferation in many cell types, including the epithelial cells of the large intestine (Tabuchi et al., 2002; Cuff et al., 2005; Thangaraju et al., 2009). The downregulation of cyclin D1 by butyrate is thought to reduce transcription initiation via histone deacetylase inhibition or, putatively, to affect histone deacetylase-independent mechanisms involving interrupted transcription elongation or GPR109A signaling (Thangaraju et al., 2009; Daroqui and Augenlicht, 2010).

The mechanisms by which butyrate downregulates cyclin D1 expression and proliferation in cell culture models appear incompatible with its in vivo effects in the promotion of ruminal epithelial growth observed in the present and previous studies (Sakata and Tamate 1978; Baldwin, 1999). Therefore, the major interest of the present study was to elucidate the gene expres- 

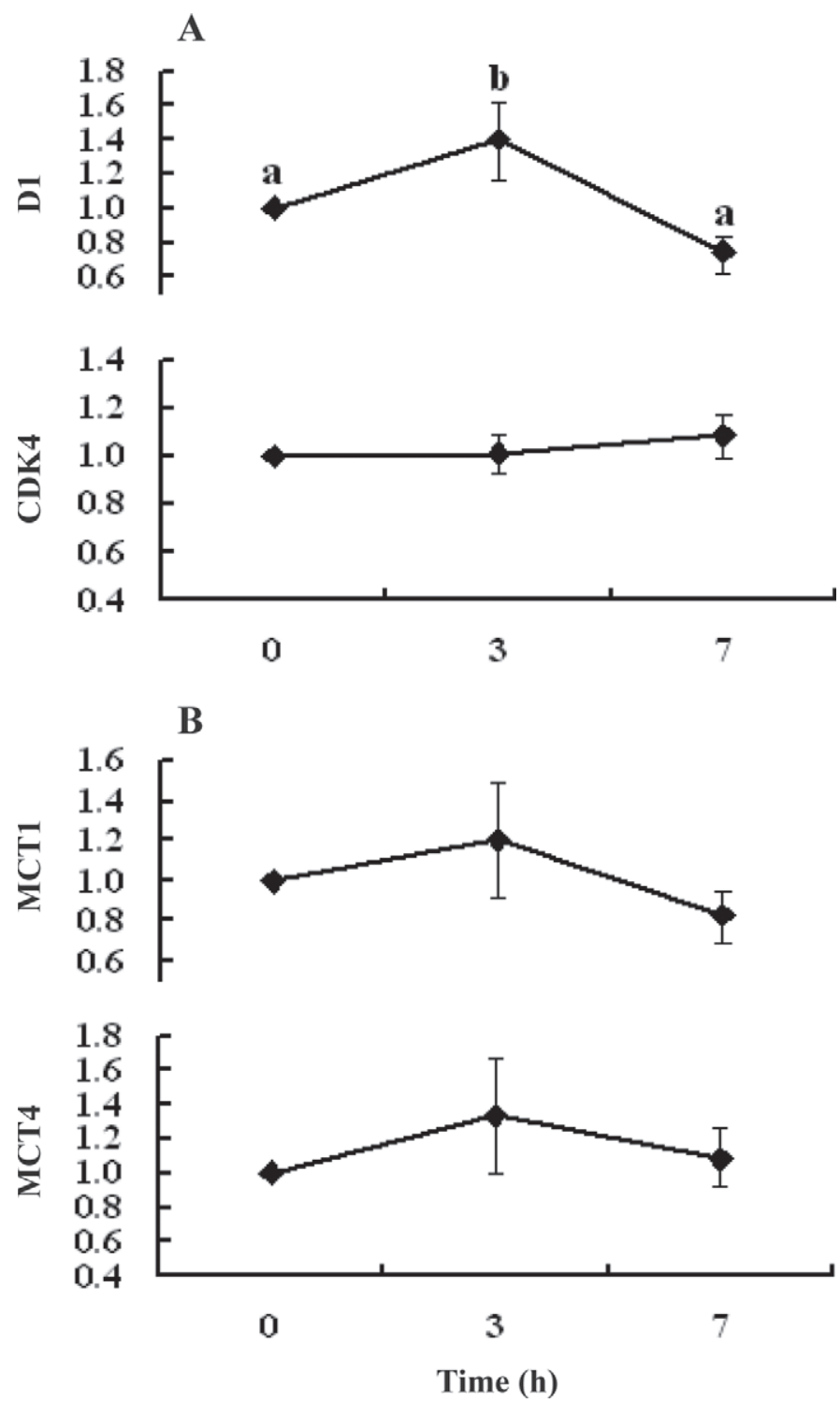

Figure 4. Effect of ruminal butyrate infusion on the mRNA expression of CCND1, CDK4, MCT1, and MCT4 (Table 2) in the ruminal epithelium of goats. Expression was normalized to $18 S \mathrm{rRNA}$. Goats $(\mathrm{n}=8)$ were infused with sodium butyrate $(0.3 \mathrm{~g} / \mathrm{kg}$ of BW per day) dissolved in $50 \mathrm{~mL}$ of $0.1 \mathrm{M}$ potassium phosphate buffer for $28 \mathrm{~d}$, and the ruminal epithelium from antrium ruminis was collected through biopsy at 0,3 , and $7 \mathrm{~h}$ after the last butyrate infusion (experiment 2). Values (means $\pm \mathrm{SE}$ ) within time curve differ if they do not share a common letter, ${ }^{\mathrm{a}, \mathrm{b}} \mathrm{P}<0.05$.

sion profile of the cell cycle regulating proteins; that is, cyclin D1 and CDK4, in ruminal epithelium with increased cell proliferation. This has led us to examine the cell cycle progression and the expression of cyclin D1 and $C D K 4$. In Exp. 1, we found no differences in cyclin D1 and CDK4 expression between groups B and $\mathrm{C}$, despite the clear evidence for epithelial proliferation seen in our morphological studies.
Sakata and Tamate $(1976,1978)$ reported that the rapid infusion of butyrate induces proliferation, whereas slow infusion does not. In this regard, the time-lag between the peak ruminal butyrate concentration and the collection of rumen epithelial samples might be important for the determination of the butyrate-inducible cell proliferation events. In Exp.1, the concentration of butyrate in the rumen was elevated for about $1.5 \mathrm{~h}$ before returning to the baseline concentration, whereas the goats were slaughtered $8 \mathrm{~h}$ after butyrate infusion, which caused a time lag of $6.5 \mathrm{~h}$ between the peak ruminal butyrate concentration and the collection of rumen epithelium samples. This has led us to speculate that the molecular effects of butyrate on cell proliferation are short lived (Liu et al., 2012) and directly related to short periods of higher butyrate concentrations in the rumen. This hypothesis was tested in Exp. 2 on 8 goats in which the feeding and butyrate infusion protocol was similar to that in Exp.1, with the only exception being that the ruminal epithelium sample was collected through biopsy at 3 consecutive time points on d 28: preinfusion and 3 and $7 \mathrm{~h}$ postinfusion. Our results showed that the expression of cyclin D1 mRNA increased $3 \mathrm{~h}$ after the infusion but returned to its preinfusion level by $7 \mathrm{~h}$ following infusion. This pattern paralleled the alterations of intraruminal butyrate concentrations, which after infusion exhibited a significant increase of butyrate by $110 \%$ for about 1.5 $\mathrm{h}$ and returned progressively to baseline concentrations thereafter. These data suggest a tight coupling between the time courses of intraruminal butyrate concentration and the expression of proliferation-inducing genes. This suggestion agrees with results from a previous study by Ohwada and Tamate (1989), in which butyrate was infused rapidly into the rumen of sheep and caused an increase in the number of dividing cells, as indicated by mitotic indices, at $4 \mathrm{~h}$ after butyrate infusion. They also observed a return of butyrate concentration to the preinfusion concentration at $7 \mathrm{~h}$ after the infusion. Cyclin D1 was identified in the present study as the molecular link between these coupled time courses of intraruminal butyrate concentration and cell proliferation. This conclusion is based on (1) the established relevance of cyclin D1 for cell cycle progression (Loyer et al., 1996); (2) the tightly coupled time course of translation of CCND1 into cyclin D1 protein (Maier et al., 2009); and (3) the extremely short half-life (30-60 min) of the cyclin D1 protein (Pardee, 1989). In contrast to cyclin D1, the expression of CDK4 remained constant at all evaluated time points. The latter finding is in agreement with an earlier observation that CDK protein levels often remain unchanged throughout the cell cycle (Noble et al., 1997), whereas those of cyclin D1 fluctuate (Pardee, 1989; Baldin et al., 1993). Coher- 
Table 6. Effects of ruminal butyrate infusion on short-chain fatty acids (SCFA) passage and absorption from the rumen of goats ${ }^{1}$

\begin{tabular}{|c|c|c|c|}
\hline \multirow[b]{2}{*}{ Item } & \multicolumn{2}{|c|}{ Group } & \multirow[b]{2}{*}{$P$-value } \\
\hline & $\mathrm{B}$ & $\mathrm{C}$ & \\
\hline Total SCFA passage $\operatorname{rate}^{2}(\% / \mathrm{h})$ & $16.3 \pm 1.2$ & $17.8 \pm 0.9$ & 0.35 \\
\hline Total SCFA absorption $\operatorname{rate}^{3}(\% / \mathrm{h})$ & $27.8 \pm 1.2$ & $23.7 \pm 0.8$ & 0.046 \\
\hline \multicolumn{4}{|c|}{$\begin{array}{l}{ }^{1} \text { Goats were infused with sodium butyrate at } 0.3(\mathrm{~B}, \mathrm{n}=8) \text { or } 0(\mathrm{C}, \mathrm{n}=7) \mathrm{g} / \mathrm{kg} \text { of BW per day in } 0.1 \mathrm{M} \text { potas- } \\
\text { sium buffer }(50 \mathrm{~mL}) \text { over } 28 \mathrm{~d} \text {, except on d } 26 \text { where the passage and absorption of SCFA in the rumen were } \\
\text { estimated by H-Val-Co marker infused in the rumen of goats (experiment } 1, \mathrm{n}=4 \text { for each group) according } \\
\text { to Resende Júnior et al. (2006) and Penner et al. (2009). Values are means } \pm \text { standard error. } \\
{ }^{2} \text { Estimated from the fractional clearance rate of Co-EDTA. }\end{array}$} \\
\hline
\end{tabular}

ent with the "butyrate paradox" (Plöger et al., 2012), the direction of cyclin D1 fluctuation upon butyrate exposure appears to be inverse during in vivo and in vitro studies. Previous studies in colonic carcinoma cells showed that butyrate exposure downregulated cyclin D1 expression at $2 \mathrm{~h}$ posttreatment (Maier et al., 2009) and Daroqui and Augenlicht (2010) demonstrated an equally fast histone hyperacetylation and chromatin remodeling of several target genes at 30 min following butyrate exposure in vitro. As such, the proliferative molecular events elicited by butyrate treatment in vivo and the antiproliferative molecular events elicited by butyrate treatment in vitro seem to have similarly fast responses, albeit inversely directed.

\section{Passage and Absorption of SCFA from Rumen}

Another intention of the present study was to investigate the relevance of the morphological changes for SCFA absorption. We used the H-Val-Co method in which valerate serves as a model SCFA, and Co serves as a fluid passage marker to distinguish between SCFA
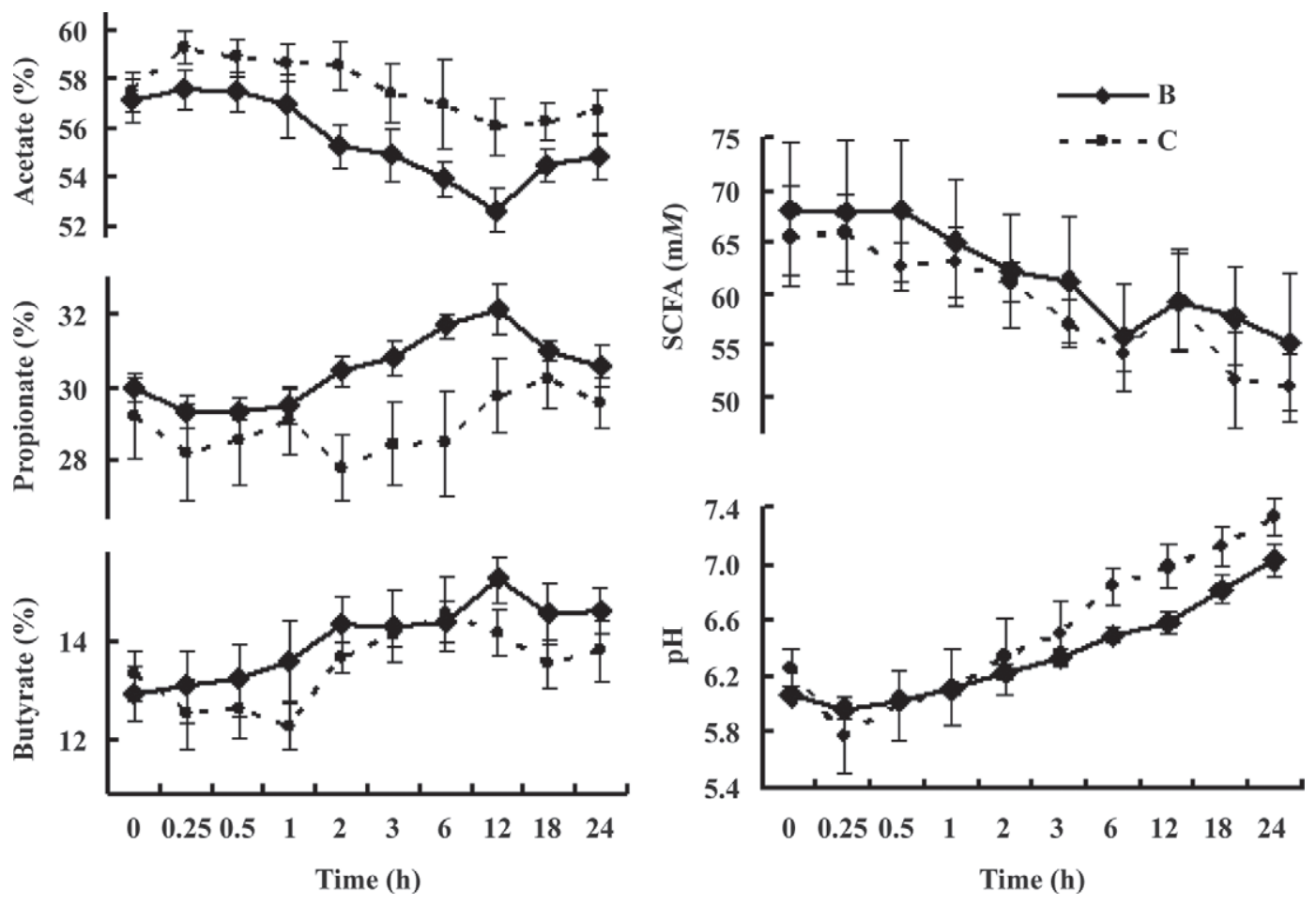

Figure 5. Molar concentration of short-chain fatty acids (SCFA; acetate, propionate, and butyrate) and their molar proportional concentrations and $\mathrm{pH}$ in the ruminal fluid of goats sampled at various time points for $24 \mathrm{~h}$ after marker (H-Val-Co) infusion on d 26 of experiment 1. Goats ( $\mathrm{n}=4$ for each group) were infused with $0.1 \mathrm{M}$ potassium phosphate buffer $(50 \mathrm{~mL})$ containing sodium butyrate at $0.3(\mathrm{~B})$ or $0(\mathrm{C}) \mathrm{g} / \mathrm{kg}$ of BW per day over 28 d. Butyrate infusion was suspended on d 26 to perform the marker infusion experiments shown here. Values are means $\pm \mathrm{SE}$ 
passage to the omasum and SCFA absorption across the reticuloruminal wall (Udén et al., 1980; Resende Júnior et al., 2006; Penner et al., 2009).

To exclude artifacts, butyrate infusion was suspended on the measurement day, because ruminal butyrate infusions are known to increase SCFA absorption rates acutely, by increasing ruminal epithelial blood flow (Storm et al., 2011), or to downregulate SCFA absorption, by reducing rumen motility (Stern et al., 1970). We were also able to exclude artifacts attributable to the different concentrations of total SCFA or changes in ruminal $\mathrm{pH}$, because these were not significantly different between groups B and C. As such, the increase in valerate disappearance across the reticuloruminal wall observed in B compared with $\mathrm{C}$ should truly represent an increase in the absorptive capacity for SCFA that is attributable to chronic effects of butyrate on the epithelial layer. This can basically be taken as evidence of the accepted concept that a larger surface area is associated with a greater absorption capacity for SCFA (Bannink et al., 2008).

Absorption of SCFA takes place via simple diffusion (for the protonated form) and via carrier-mediated transport (for the anionic form; Koho et al., 2005; Aschenbach et al., 2009, 2011). The relative contributions of simple diffusion and carrier-mediated transport have not been determined for intraruminal valerate; however, simple diffusion increases with increasing chain length of SCFA (Sehested et al., 1999; Aschenbach et al., 2009, 2011) and available absorptive surface area (Dirksen et al., 1984). Valerate, as the longest of all SCFA, should, therefore, be highly representative of the diffusion component of SCFA absorption.

In addition to the simple diffusion of nonionic SCFA, a significant amount of SCFA is absorbed in ionic form through carrier-mediated transport. Two isoforms of monocarboxylate transporters have been suggested to participate in SCFA absorption across the ruminal epithelium, namely MCT1 and MCT4 (Müller et al., 2002; Kirat et al., 2007). The former is localized at the basolateral side of the ruminal epithelium (Müller et al., 2002; Graham et al., 2007; Kirat et al., 2007), and its role has been suggested in the efflux of SCFA and, especially, their metabolites (ketone bodies and lactate) from the epithelium into the blood (Müller et al., 2002; Kirat et al., 2007). Moreover, recent studies have indicated the diet-dependent upregulation of ruminal MCT1 at both the mRNA and the protein levels (Koho et al., 2011; Laarman et al., 2012). Both groups of authors indirectly conclude that a possible link exists between MCT1 upregulation and the concurrently increased luminal butyrate availability, because concentration-dependent and time-dependent increases in MCT1 mRNA and protein have been observed in cultured colonic epithelial cells (Cuff et al., 2002). In the present study, however, ruminal butyrate infusion in vivo induced neither short-term nor long-term effects on MCT1 expression. This agrees with results of a recent study in Holstein cows in which $M C T 1$ mRNA is also not altered by ruminal butyrate infusions in vivo (Baldwin et al., 2012). In contrast, the expression of MCT4 mRNA increases by $135 \%$ after long-term ruminal butyrate infusions. Monocarboxylase transporter 4 is localized to the apical membrane of the ruminal epithelium (Koho et al., 2005; Kirat et al., 2007). In contrast to MCT1, however, a major role of MCT4 in ruminal SCFA absorption is not supported at present, because the prototypical MCT4 substrate lactate is poorly absorbed from the ruminal content (Williams and Mackenzie, 1965; Aschenbach et al., 2009). Despite the unproven functional significance of ruminal MCT4, the present study is the first to show its dietary regulation. A previous study comparing MCT4 expression in captive versus free-ranging reindeer has not established a difference between the 2 groups (Koho et al., 2005). Nonetheless, our results appear to mirror the results obtained previously in a breast cancer cell line, in which butyrate treatment led to the overexpression of MCT4 with no change in MCT1 (Cuff et al., 2005; Queirós et al., 2012).

\section{CONCLUSIONS}

We conclude that rapid changes in cyclin D1, together with a constant level of expression of $C D K_{4}$, allow butyrate to exert acute and one-off effects on cell cycle progression in the ruminal epithelium. To our knowledge, this is the first report on the molecular basis of cell cycle effects of butyrate in the ruminal epithelium. The subsequently induced proliferation leads to increases in both surface area and epithelial thickness and is associated with an increased capacity for SCFA absorption. Increased absorption has been established for valerate, for which a predominance of diffusive uptake can be postulated. Concurrent increases in MCT4 mRNA suggest that carrier-mediated SCFA transport is also upregulated by butyrate, although this has to be substantiated in future studies.

\section{ACKNOWLEDGMENTS}

This work was supported by the Chinese National "973" Project (No. 2011CB100801), the Priority Academic Program Development of Jiangsu Higher Education Institutions (PAPD), and in part by Sindh Agriculture University (Tandojam, Pakistan). 


\section{REFERENCES}

AOAC. 1990. Official Methods of Analysis. 15th ed. Assoc. Off. Anal. Chem., Washington, DC.

Aschenbach, J. R., S. Bilk, G. Tadesse, F. Stumpff, and G. Gäbel. 2009. Bicarbonate-dependent and bicarbonate-independent mechanisms contribute to nondiffusive uptake of acetate in the ruminal epithelium of sheep. Am. J. Physiol. Gastrointest. Liver Physiol. 296:G1098-G1107.

Aschenbach, J. R., G. B. Penner, F. Stumpff, and G. Gäbel. 2011. Ruminant Nutrition Symposium: Role of fermentation acid absorption in the regulation of ruminal pH. J. Anim. Sci. 89:1092-1107.

Baldin, V., J. Lukas, M. J. Marcote, M. Pagano, and G. Draetta. 1993. Cyclin D1 is a nuclear-protein required for cell-cycle progression in G1. Genes Dev. 7:812-821.

Baldwin, R. L. 1999. The proliferative actions of insulin, insulin-like growth factor-I, epidermal growth factor, butyrate and propionate on rumen epithelial cells in vitro. Small Rumin. Res. 32:261-268.

Baldwin, R. L. 2000. Sheep gastrointestinal development in response to different dietary treatments. Small Rumin. Res. 35:39-47.

Baldwin, R. L., S. Wu, W. Li, C. Li, B. J. Bequette, and R. W. Li. 2012. Quantification of transcriptome responses of the rumen epithelium to butyrate infusion using RNA-seq technology. Gene Regul. Syst. Biol. 6:67-80.

Bannink, A., J. France, S. Lopez, W. J. J. Gerrits, E. Kebreab, S. Tamminga, and J. Dijkstra. 2008. Modelling the implications of feeding strategy on rumen fermentation and functioning of the rumen wall. Anim. Feed Sci. Technol. 143:3-26.

Bergman, E. N. 1990. Energy contributions of volatile fatty acids from the gastrointestinal tract in various species. Physiol. Rev. 70:567-590.

Chomczynski, P., and N. Sacchi. 2006. The single-step method of RNA isolation by acid guandinium thiocyanate-phenol-chloroform extraction: Twenty-something years on. Nat. Protoc. 1:581-585.

Cuff, M. A., J. Dyer, M. Jones, and S. P. Shiraz-Beechey. 2005. The human colonic monocarboxylate transporter isoform 1: Its potential importance to colonic tissue homeostasis. Gastroenterology 128:676-686

Cuff, M. A., D. W. Lambert, and S. P. Shiraz-Beechey. 2002. Substrate-induced regulation of the human colonic monocarboxylate transporter, MCT1. J. Physiol. 539:361-371.

Daroqui, M. C., and L. H. Augenlicht. 2010. Transcriptional attenuation in colon carcinoma cells in response to butyrate. Cancer Prev. Res. (Phila.) 3:1292-1302.

Dirksen, G., H. G. Liebich, G. Brosi, H. Hegemeister, and E. Mayer. 1984. Morphology of the rumen mucosa and fatty acid absorption in cattle-important factors for health and production. Zentralbl. Veterinarmed. A 31:414-430.

Dobson, A. 1984. Blood flow and absorption from the rumen. Q. J. Exp. Physiol. 69:599-606.

Gäbel, G., J. R. Aschenbach, and F. Müller. 2002. Transfer of energy substrates across the ruminal epithelium: Implication and limitations. Anim. Health Res. Rev. 3:15-30.

Gäbel, G., M. Bestmann, and H. Martens. 1991a. Influence of diet, short-chain fatty acids, lactate and chloride on bicarbonate movement across the reticulorumen wall of sheep. Zentralbl. Veterinarmed. A 38:523-529.

Gäbel, G., H. Martens, M. Suendermann, and P. Galfi. 1987. The effect of diet, intraruminal $\mathrm{pH}$ and osmolarity on sodium, chloride and magnesium absorption from the temporary isolated and washed reticulo-rumen of sheep. Q. J. Exp. Physiol. Cogn. Med. Sci. 72:501-511.

Gäbel, G., S. Vogler, and H. Martens. 1991b. Short-chain fatty acids and $\mathrm{CO}_{2}$ as regulators of $\mathrm{Na}^{+}$and $\mathrm{Cl}^{-}$absorption in isolated sheep rumen mucosa. J. Comp. Physiol. B 161:419-426.

Galfi, P., S. Neogrády, and F. Kutas. 1986. Dissimilar ruminal epithelial response to short-term and continuous intraruminal infusion of sodium n-butyrate. Zentralbl. Veterinarmed. A 33:47-52.

Gorka, P., Z. M. Kowalski, P. Pietrzak, A. Kotunia, R. Kiljanczyk, J. Flaga, J. J. Holst, P. Guilloteau, and R. Zabielski. 2009. Effect of sodium butyrate supplementation in milk replacer and starter diet on rumen development in calves. J. Physiol. Pharmacol. 60:47-53.

Graham, C., I. Gatherar, I. Haslam, M. Glanville, and N. L. Simmons. 2007. Expression and localization of monocarboxlate transportes and sodium/proton exchangers in bovine rumen epithelium. Am. J. Physiol. Regul. Integr. Comp. Physiol. 292:R997-R1007.

Hamer, H. M., D. Jonkers, K. Venema, S. Vanhoutvin, F. J. Troost, and R. J. Brummer. 2008. Review article: The role of butyrate on colonic function. Aliment. Pharmacol. Ther. 27:104-119.

Huhtanen, P., H. Miettinen, and M. Ylinen. 1993. Effect of increasing ruminal butyrate on milk-yield and blood-constituents in dairycows fed a grass silage-based diet. J. Dairy Sci. 76:1114-1124.

Kauffold, P., J. Voigt, and G. Herrendörfer. 1977. The effect of nutritional factors on the ruminal mucosa. 3. Conditions of the mucosa after infusion of propionic acid, acetic acid and butyric acid. Arch. Tierernahr. 27:201-211.

Kendall, P. E., and L. M. McLeay. 1996. Excitatory effects of volatile fatty acids on the in vitro motility of the rumen of sheep. Res. Vet. Sci. 61:1-6.

Kien, C. L., C. P. Peltier, S. Mandal, J. R. Davie, and R. Blauwiekel. 2008. Effects of the in vivo supply of butyrate on histone acetylation of cecum in piglets. JPEN J. Parenter. Enteral Nutr. 32:5156 .

Kirat, D., Y. Matsuda, N. Yamashiki, H. Hayashi, and S. Kato. 2007. Expression, cellular localization, and functional role of monocarboxylate transporter 4 (MCT4) in the gastrointestinal tract of ruminants. Gene 391:140-149.

Koho, N. M., V. Maijala, H. Norberg, M. Nieminen, and A. R. Poso. 2005. Expression of MCT1, MCT2 and MCT4 in the rumen, small intestine and liver of reindeer (Rangifer tarandus tarandus L.). Comp. Biochem. Physiol. A Integr. Physiol. 141:29-34.

Koho, N. M., J. Taponen, H. Tiihonen, M. Nieminen, and A. R. Poso. 2011. Effects of age and concentrate feeding on the expression of MCT1 and CD147 in the gastrointestinal tract of goats and Hereford finishing beef bulls. Res. Vet. Sci. 90:301-305.

Krehbiel, C. R., D. L. Harmon, and J. E. Schnieder. 1992. Effect of increasing ruminal butyrate on portal and hepatic nutrient flux in steers. J. Anim. Sci. 70:904-914.

Kristensen, N. B., and D. L. Harmon. 2004. Effect of increasing butyrate absorption on splamchnic metabolism of volatile fatty acids absorbed from the washed reticulorumen of steers. J. Anim. Sci. 82:3549-3559.

Laarman, A. H., A. L. Ruiz-Sanchez, T. Sugino, L. L. Guan, and M. Oba. 2012. Effects of feeding a calf starter on molecular adaptations in the ruminal epithelium and liver of Holstein dairy calves. J. Dairy Sci. 95:2585-2594.

Liu, L., G. Song, F. Gao, J. Guan, B. Tang, and Z. Li. 2012. Transient exposure to sodium butyrate after germinal vesicle breakdown improves meiosis but not developmental competence in pig oocytes. Cell Biol. Int. 36:483-490.

Livak, K. J., and T. D. Schmittgen. 2001. Analysis of relative gene expression data using real-time quantitative PCR and the $2^{-\triangle \Delta C T}$ method. Methods 25:402-408.

Loyer, P., S. Cariou, D. Glaise, M. Bilodeau, G. Baffet, and C. Guguen-Guillouzo. 1996. Growth factor dependence of progression through $\mathrm{G}(1)$ and $\mathrm{S}$ phases of adult rat hepatocytes in vitroEvidence of a mitogen restriction point in mid-late G(1). J. Biol. Chem. 271:11484-11492.

Maier, S., M. C. Daroqui, S. Scherer, S. Roepcke, A. Velcich, S. M. Shenoy, R. H. Singer, and L. H. Augenlicht. 2009. Butyrate and vitamin D3 induce transcriptional attenuation at the cyclin D1 locus in colonic carcinoma cells. J. Cell. Physiol. 218:638-642.

Mathew, O. P., K. Ranganna, and F. M. Yatsu. 2010. Butyrate, an HDAC inhibitor, stimulates interplay between different posttranslational modifications of histone H3 and differently alters G1-specific cell cycle proteins in vascular smooth muscle cells. Biomed. Pharmacother. 64:733-740.

Mentschel, J., R. Leiser, C. Mulling, C. Pfarrer, and R. Claus. 2001. Butyric acid stimulates rumen mucosa development in the calf mainly by a reduction of apoptosis. Arch. Tierernahr. 55:85-102. 
Müller, F., K. Huber, H. Pfannkuche, J. R. Aschenbach, G. Breves, and G. Gäbel. 2002. Transport of ketone bodies and lactate in the sheep ruminal epithelium by monocarboxylate transporter 1 . Am. J. Physiol. Gastrointest. Liver Physiol. 283:G1139-G1146.

Neogrády, Z., P. Galfi, and F. Kutas. 1989. Effect of intraruminal butyrate infusion on the plasma-insulin level in sheep. Acta Vet. Hung. 37:247-253.

Noble, M. E. M., J. A. Endicott, N. R. Brown, and L. N. Johnson. 1997. The cyclin box fold: Protein recognition in cell-cycle and transcription control. Trends Biochem. Sci. 22:482-487.

Nozière, P., C. Martin, D. Remond, N. B. Kristensen, R. Bernard, and M. Doreau. 2000. Effect of composition of ruminally-infused shortchain fatty acids on net fluxes of nutrients across portal-drained viscera in underfed ewes. Br. J. Nutr. 83:521-531.

Ohwada, S., and H. Tamate. 1989. Influence of sodium butyrate and tributyrin on mitotic index in sheep ruminal epithelium. Asianaustralas. J. Anim. Sci. 2:518-519.

Pardee, A. B. 1989. G1 events and regulation of cell-proliferation. Science 246:603-608.

Penner, G. B., M. A. Steele, J. R. Aschenbach, and B. W. McBride. 2011. Ruminant Nutrition Symposium: Molecular adaptation of ruminal epithelia to highly fermentable diets. J. Anim. Sci. 89:1108-1119

Penner, G. B., M. Taniguchi, L. L. Guan, K. A. Beauchemin, and M. Oba. 2009. Effect of dietary forage to concentrate ratio on volatile fatty acid absorption and the expression of genes related to volatile fatty acid absorption and metabolism in ruminal tissue. J. Dairy Sci. 92:2767-2781.

Plöger, S., F. Stumpff, G. B. Penner, J. D. Schulzke, G. Gäbel, H. Martens, Z. Shen, D. Gunzel, and J. R. Aschenbach. 2012. Microbial butyrate and its role for barrier function in the gastrointestinal tract. Ann. N. Y. Acad. Sci. 1258:52-59.

Queirós, O., A. Preto, A. Pacheco, C. Pinheiro, J. Azevedo-Silva, R. Moreira, M. Pedro, Y. H. Ko, P. L. Pedersen, F. Baltazar, and M. Casal. 2012. Butyrate activates the monocarboxylate transporter MCT4 expression in breast cancer cells and enhances the antitumor activity of 3-bromopyruvate. J. Bioenerg. Biomembr. 44:141-153.

Resende Júnior, J. C., M. N. Pereira, H. Boer, and S. Tamminga. 2006. Comparison of techniques to determine the clearance of ruminal volatile fatty acids. J. Dairy Sci. 89:3096-3106.

Rhee, K. C. 2005. Determination of total nitrogen. Pages 105-113 in Handbook of Food Analytical Chemistry: Water, Proteins, Enzymes, Lipids, and Carbohydrates. R. E. Wrolstad, E. A. Decker, S. J. Schwartz, and P. Sporns, ed. John Wiley \& Sons, Hoboken, NJ.

Sakata, T., and H. Tamate. 1976. Effect of intraruminal injection of nsodium butyrate on the mitotic indices in sheep rumen epithelium. Tohoku J. Agric. Res. 27:3-4.

Sakata, T., and H. Tamate. 1978. Rumen epithelial cell proliferation accelerated by rapid increase in intraruminal butyrate. J. Dairy Sci. 61:1109-1113.
Sander, E. G., R. G. Warner, H. N. Harrison, and J. K. Loosli. 1959 The stimulatory effect of sodium butyrate and sodium propionate on the development of rumen mucosa in the young calf. J. Dairy Sci. 42:1600-1605.

Sehested, J., L. Diernaes, P. D. Moller, and E. Skadhauge. 1999. Ruminal transport and metabolism of short-chain fatty acids (SCFA) in vitro: Effect of SCFA chain length and $\mathrm{pH}$. Comp. Biochem. Physiol. A Mol. Integr. Physiol. 123:359-368.

Shen, Z. M., S. Kuhla, R. Zitnan, H. M. Seyfert, F. Schneider, H Hagemeister, A. Chudy, B. Lohrke, J. Blum, H. M. Hammon, and J. Voigt. 2005. Intraruminal infusion of n-butyric acid induces an increase of ruminal papillae size independent of IGF-1 system in castrated bulls. Arch. Anim. Nutr. 59:213-225.

Shen, Z. M., H. M. Seyfert, B. Lohrke, F. Schneider, R. Zitnan, A. Chudy, S. Kuhla, H. M. Hammon, J. W. Blum, H. Martens, H. Hagemeister, and J. Voigt. 2004. An energy-rich diet causes rumen papillae proliferation associated with more IGF type 1 receptors and increased plasma IGF-1 concentrations in young goats. J. Nutr. 134:11-17.

Stern, J. S. C. A. Baile, and J. Mayer. 1970. Are propionate and butyrate physiological regulators of plasma insulin in ruminants? Am. J. Physiol. 219:84-91.

Storm, A. C., M. D. Hanigan, and N. B. Kristensen. 2011. Effects of ruminal ammonia and butyrate concentrations on reticuloruminal epithelial blood flow and volatile fatty acid absorption kinetics under washed reticulorumen conditions in lactating dairy cows. J. Dairy Sci. 94:3980-3994.

Storm, A. C., N. B. Kristensen, and M. D. Hanigan. 2012. A model of ruminal volatile fatty acid absorption kinetics and rumen epithelial blood flow in lactating Holstein cows. J. Dairy Sci. 95:2919-2934.

Tabuchi, Y., Y. Arai, T. Kondo, N. Takeguchi, and S. Asano. 2002 Identification of genes responsive to sodium butyrate in colonic epithelial cells. Biochem. Biophys. Res. Commun. 293:1287-1294.

Thangaraju, M., G. A. Cresci, K. Liu, S. Ananth, J. P. Gnanaprakasam, D. D. Browning, J. D. Mellinger, S. B. Smith, G. J. Digby, N. A. Lambert, P. D. Prasad, and V. Ganapathy. 2009. GPR109A is a G-protein-coupled receptor for the bacterial fermentation product butyrate and functions as a tumor suppressor in colon. Cancer Res. 69:2826-2832.

Udén, P., P. E. Colucci, and P. J. Van Soest. 1980. Investigation of chromium, cerium and cobalt as markers in digesta. Rate of passage studies. J. Sci. Food Agric. 31:625-632.

Williams, V. J., and D. D. Mackenzie. 1965. The absorption of lactic acid from the reticulo-rumen of the sheep. Aust. J. Biol. Sci. 18:917-934.

Yang, W., Z. Shen, and H. Martens. 2012. An energy-rich diet enhances expression of $\mathrm{Na}^{+} / \mathrm{H}^{+}$exchanger isoform 1 and 3 messenger RNA in rumen epithelium of goat. J. Anim. Sci. 90:307-317. 